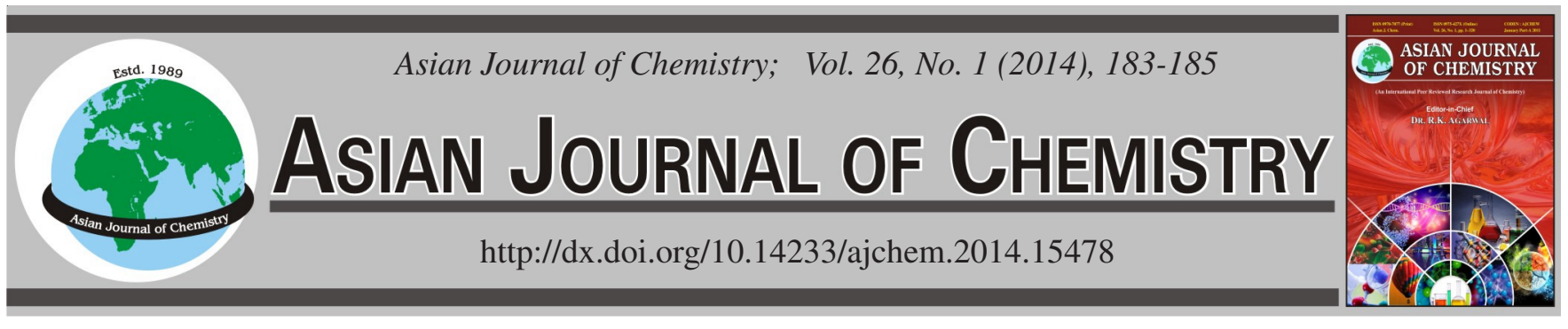

\title{
Synthesis, Characterization and Crystal Structure of Nickel Complex $(\mathrm{dppv}) \mathrm{Ni}_{(}\left(\mathrm{C}_{7} \mathrm{H}_{4} \mathrm{NS}_{2}\right)_{2}$
}

\author{
Yu-Long Li ${ }^{1,2, *}$, Bin XIE ${ }^{2}$, Li-Ke Zou ${ }^{1}, \mathrm{XIAO}_{\mathrm{LiN}}^{2}$ and Sha-Sha Zhu ${ }^{2}$
}

${ }^{1}$ Key Laboratory of Green Catalysis of Higher Education Institutes of Sichuan, Sichuan University of Science \& Engineering, Zigong 643000, P.R. China

${ }^{2}$ Institute of Functional Materials, Sichuan University of Science \& Engineering, Zigong 643000, P.R. China

*Corresponding author: Fax: +86 813 5505606; Tel: +86 813 5505601; E-mail: yu_longli@yahoo.cn

Received: 13 March 2013;

Accepted: 20 July 2013;

Published online: 26 December 2013;

AJC-14500

Reaction of 2-mercaptobenzothiazole with $(\mathrm{dppv}) \mathrm{NiCl}_{2}\left(\mathrm{dppv}: \mathrm{Ph}_{2} \mathrm{PCH}=\mathrm{CHPPh}_{2}\right)$ in the presence of $\mathrm{Et}_{3} \mathrm{~N}$ affords the title complex (dppv)Ni( $\left(\mathrm{C}_{7} \mathrm{H}_{4} \mathrm{NS}_{2}\right)_{2}$ in $92 \%$ yield. The new complex was fully characterized by elemental analysis, TGA, IR and ${ }^{1} \mathrm{H}\left({ }^{13} \mathrm{C},{ }^{31} \mathrm{P}\right) \mathrm{NMR}$ spectroscopies. In addition, the molecular structure of the title complex was established by X-ray crystallography. The crystal of (dppv)Ni( $\left.\mathrm{C}_{7} \mathrm{H}_{4} \mathrm{NS}_{2}\right)_{2} \cdot \mathrm{CH}_{2} \mathrm{Cl}_{2}$ crystallizes in monoclinic, space group P2/n with a = 15.927(9), b = 8.3553(5), c = 16.3728(8) $\AA$, $\alpha=90.00$, $\beta=112.417(4), \gamma=90.00^{\circ}, \mathrm{V}=2014.22(19) \AA^{3}, \mathrm{Z}=2, \mathrm{C}_{40} \mathrm{H}_{30} \mathrm{~N}_{2} \mathrm{NiP}_{2} \mathrm{~S}_{4} \cdot \mathrm{CH}_{2} \mathrm{Cl}_{2}, \mathrm{M}_{\mathrm{r}}=872.48, \mathrm{D}_{\mathrm{c}}=1.439 \mathrm{~g} / \mathrm{cm}^{3}, \mathrm{~F}(000)=896$ and $\mu\left(\mathrm{MoK}_{\alpha}\right)=0.934 \mathrm{~mm}^{-1}$. The final $\mathrm{R}=0.0920$ and $\mathrm{wR}=0.2220$ for 2572 observed reflections with $\mathrm{I}>2 \sigma(\mathrm{I})$ and $\mathrm{R}=0.1171$ and $w \mathrm{R}=$ 0.2434 for all data. The geometry at the Ni centre in the title complex is square-planar with the $\mathrm{NiP}_{2} \mathrm{~S}_{2}$ chromophore.

Keywords: dppv, 2-Mercaptobenzothiazole, Synthesis, X-ray crystallography.

\section{INTRODUCTION}

Since the discovery of nickel could be used in place of palladium in Suzuki-type coupling of boronic acids and the active site of $[\mathrm{NiFe}]$ hydrogenases consists of a $\left[\mathrm{NiFe}_{2} \mathrm{~S}\right]$ cluster core, (diphosphine) $\mathrm{NiCl}_{2}$ (diphosphine = dppe, dppv, $\mathrm{dppf}$ ) have been received special attention ${ }^{1-6}$. A series of [NiFe] hydrogenases models (dppe) $\mathrm{Ni}(\mu-\mathrm{S})_{2} \mathrm{Fe}_{2}(\mathrm{CO})_{6}$ and (dppf)Ni( $\mu$ $\mathrm{S})_{2} \mathrm{Fe}_{2}(\mathrm{CO})_{6}$ have been synthesized by treatment of $(\mu-$ $\mathrm{SLi})_{2} \mathrm{Fe}_{2}(\mathrm{CO})_{6}$ with (dppe) $\mathrm{NiCl}_{2}$ and (dppf) $\mathrm{NiCl}_{2}$, respectively ${ }^{7-11}$. Especially, Schmidt prepared an important complex (dppe)Ni(pdt) by reaction of (dppe) $\mathrm{NiCl}_{2}$ with $\mathrm{HSCH}_{2} \mathrm{CH}_{2} \mathrm{CH}_{2} \mathrm{SH}^{12,13}$, which has been used to synthesized [NiFe] hydrogenases model complex (dppe) $\mathrm{Ni}\left(\mu\right.$-pdt) $\mathrm{Fe}(\mathrm{CO})_{3}{ }^{14}$, that attracted our interest. Here we reported the synthesis, characterization and crystal structure of (dppv)Ni( $\left.\mathrm{C}_{7} \mathrm{H}_{4} \mathrm{NS}_{2}\right)_{2}$ (I) (Scheme-1), we expect it can be used to synthesize the [NiFe] hydrogenases models.

\section{EXPERIMENTAL}

All reactions were carried out in a $\mathrm{N}_{2}$ atmosphere using standard Schlenk techniques. All solvents were dried using standard procedures and distilled under $\mathrm{N}_{2}$. $\mathrm{Ni}(\mathrm{dppv}) \mathrm{Cl}_{2}{ }^{15}$ was prepared according to literature procedures. Some other materials were available commercially. Melting points were determined on a SGW X-4 microscopic melting point apparatus and were uncorrected. Elemental analyses for carbon, hydrogen<smiles></smiles>

(I)

Scheme-I: Structure of Ni(II) complex (I)

were performed on a Perkin-Elmer 240C analyzer. IR spectra were recorded at room temperature on a Bruker Vector 22 infrared spectrophotometer. ${ }^{1} \mathrm{H}\left({ }^{13} \mathrm{C},{ }^{31} \mathrm{P}\right) \mathrm{NMR}$ spectra were obtained on a Varian Mercury Plus 400 NMR spectrometer. TGA measurement was carried out on a NETZSCH STA 409 PC/PG instrument.

Synthetic procedure: A solution of $\mathrm{Ni}(\mathrm{dppv}) \mathrm{Cl}_{2}(0.263 \mathrm{~g}$, $0.5 \mathrm{mmol})$ in THF $(15 \mathrm{~mL})$ was treated with 2-mercaptobenzothiazole $(0.167 \mathrm{~g}, 1 \mathrm{mmol})$ in the presence of $\mathrm{Et}_{3} \mathrm{~N}(0.140$ $\mathrm{mL}, 1 \mathrm{mmol})$. The mixture was stirred at room temperature for $1 \mathrm{~h}$, volatiles were removed under vacuum and the residue was subjected to TLC using $\mathrm{CH}_{2} \mathrm{Cl}_{2} / n$-hexane (v/v = 5:1) as eluent. From the main red band, the title complex (I) $(0.360 \mathrm{~g}$, $92 \%$ ) was obtained as a red solid. m.p.: $214-216{ }^{\circ} \mathrm{C}$. Anal. 
calcd. (\%) for $\mathrm{C}_{40} \mathrm{H}_{30} \mathrm{~N}_{2} \mathrm{NiP}_{2} \mathrm{~S}_{4}: \mathrm{C}, 61.00, \mathrm{H}, 3.84, \mathrm{~N}: 3.56$; Found : C, 61.27, H, 3.92, N, 3.48. IR (KBr, $\left.v_{\max }, \mathrm{cm}^{-1}\right)$ : 3052, $1642,1485,1433,1102,1076,1034,995,751,724,691 .{ }^{1} \mathrm{H}$ NMR (400 MHz, DMSO, TMS) $\delta$ ppm: 7.08-7.85 (m, 30H, $\left.4 \mathrm{C}_{6} \mathrm{H}_{5}, 2 \mathrm{C}_{6} \mathrm{H}_{4}, \mathrm{CH}=\mathrm{CH}\right) \mathrm{ppm} .{ }^{13} \mathrm{C}$ NMR (100.6 MHz, DMSO, TMS) $\delta$ ppm: 113.11, 122.11, 124.49, 127.48, 128.97, 131.95, 133.94, 133.97, 142.40 $\left(\mathrm{C}_{6} \mathrm{H}_{5}, \mathrm{C}_{6} \mathrm{H}_{4}, \mathrm{CH}=\mathrm{CH}\right), 190.09(\mathrm{C}=\mathrm{N})$. ${ }^{31} \mathrm{P}$ NMR (162 MHz, DMSO, $\left.85 \% \mathrm{H}_{3} \mathrm{PO}_{4}\right) \delta$ ppm: 64.73 (s).

Crystal structure determination: Single crystal of the present nickel complex (I) suitable for X-ray diffraction analysis was grown by slow evaporation of the $\mathrm{CH}_{2} \mathrm{Cl}_{2}$ /hexane solution at $-10{ }^{\circ} \mathrm{C}$. The crystal of $(\mathbf{I})$ with dimensions of $0.28 \mathrm{~mm} \times$ $0.24 \mathrm{~mm} \times 0.21 \mathrm{~mm}$ was mounted on a CCD area detector equipped with a graphite-monochromated $\operatorname{MoK}_{\alpha}$ radiation $(\lambda=$ $0.71073 \AA$ ) by using by using an $\omega$ scan mode at $296(2) \mathrm{K}$ in the range of $1.52^{\circ} \leq \theta \leq 25.01^{\circ}$. The crystal belongs to monoclinic system with space group $\mathrm{P} 2 / \mathrm{n}$ and crystal parameters of $\mathrm{a}=15.927(9) \AA, \mathrm{b}=8.3553(5) \AA, \mathrm{c}=16.3728(8) \AA, \alpha=$ $90.00^{\circ}, \beta=112.417(4)^{\circ}, \gamma=90.00^{\circ}, \mathrm{V}=2014.22(19) \AA^{3}$, $\mathrm{D}_{\mathrm{c}}=1.439 \mathrm{~g} / \mathrm{cm}^{3}$. The absorption coefficient $\mu=0.934 \mathrm{~mm}^{-1}$ and $\mathrm{Z}=2$. Absorption correction was performed by the CRYSTALCLEAR program ${ }^{16}$. The structure was solved by direct methods using the SHELXS-97 program $^{17}$ and refined by full-matrix least-squares techniques on $\mathrm{F}^{2}$ data using SHELXL-97 ${ }^{18}$. The empirical absorption corrections were applied to all intensity data. All the Hydrogen atoms were located by using the geometric method, with $\mathrm{d}(\mathrm{C}-\mathrm{H})=0.95-$ $0.98 \AA$ and $\mathrm{U}_{\text {iso }}(\mathrm{H})=1.2 \mathrm{U}_{\mathrm{eq}}(\mathrm{C})$ or $1.5 \mathrm{U}_{\text {eq }}\left(\mathrm{C}_{\text {methyl }}\right)$. The final full-matrix least squares refinement gave $\mathrm{R}=0.0920$, $\mathrm{wR}=$ $0.2220\left(\mathrm{w}=1 /\left[\sigma^{2}\left(\mathrm{~F}_{\mathrm{o}}\right)^{2}+(0.1021 \mathrm{P})^{2}+10.4125 \mathrm{P}\right]\right.$, where $\mathrm{P}=$ $\left.\left(\mathrm{F}_{\mathrm{o}}^{2}+2 \mathrm{~F}_{\mathrm{c}}^{2}\right) / 3\right), \mathrm{S}=1.089,(\Delta / \sigma)_{\max }=0.001,(\Delta \rho)_{\max }=1.380$ and $(\Delta \rho)_{\min }=-1.120 \mathrm{e} / \AA^{3}$.

\section{RESULTS AND DISCUSSION}

The single crystal of the present complex (I) was obtained by slow diffusion of $n$-hexane to the dichloromethane solution of the complex, which was crystallized as air-stable red crystals. The elemental analyses, IR and NMR spectra are in good agreement with the formulae proposed by the X-ray crystallography.

Structure of the title complex (I): Crystallographic and refinement parameters are listed in Table-1. The selected bond lengths and angles are given in Tables 2 and 3. The structure was solved by direct methods. Anisotropic displacement parameters were applied to all non-hydrogen atoms in fullmatrix least-square refinements based on $\mathrm{F}_{2}$. The hydrogen atoms were set in calculated positions with a common fixed isotropic thermal parameter.

The molecular structure of the present nickel complex (I) was determined by X-ray diffraction ORTEP and crystal packing diagram of the title complex (I) are shown in Figs. 1 and 2 , respectively.

As can be seen in Fig. 1, the crystal of the complex (I) contain a dichloromethane molecule, the geometry at the $\mathrm{Ni}$ centre in the title complex (I) is square -planar with the $\mathrm{NiP}_{2} \mathrm{~S}_{2}$ chromophore. The Ni atom is coordinated by two sulfur atoms from 2-mercaptobenzothiazole and two phosphorus atoms from dppv ligand. The crystallographic study of the title complex (I) revealed that the Ni(1)-P(1) bond length (2.1437(19) $\AA$ ) is shorter than the corresponding bond of

\begin{tabular}{|c|c|}
\hline \multicolumn{2}{|c|}{ TABLE-1 } \\
\hline Items & Values \\
\hline Empirical formula & $\mathrm{C}_{41} \mathrm{H}_{32} \mathrm{Cl}_{2} \mathrm{~N}_{2} \mathrm{NiP}_{2} \mathrm{~S}_{4}$ \\
\hline Formula weight & 872.48 \\
\hline Crystal system & Monoclinic \\
\hline \multicolumn{2}{|l|}{ Unit cell dimensions } \\
\hline $\mathrm{a}\left(\AA{ }^{\circ}\right)$ & $15.9275(9)$ \\
\hline $\mathrm{b}\left(\AA,{ }^{\circ}\right)$ & $8.3553(5)$ \\
\hline $\mathrm{c}\left(\AA,{ }^{\circ}\right)$ & $16.3728(8)$ \\
\hline \multicolumn{2}{|l|}{ Unit cell angles $\left({ }^{\circ}\right)$} \\
\hline$\alpha$ & 90.00 \\
\hline$\beta$ & $112.417(4)$ \\
\hline$\gamma$ & 90.00 \\
\hline Volume $\left(\AA^{3}\right)$ & 2014.22(19) \\
\hline $\mathrm{Z}$ & 2 \\
\hline Temperature $(\mathrm{K})$ & $296(2)$ \\
\hline Space group & $\mathrm{P} 2 / \mathrm{n}$ \\
\hline Wavelength $(\AA)$ & 0.71073 \\
\hline Calculated density $\left(\mathrm{g} \mathrm{cm}^{-3}\right)$ & 1.439 \\
\hline Absorption coefficient $\mu\left(\mathrm{mm}^{-1}\right)$ & 0.934 \\
\hline $\mathrm{F}(000)$ & 896 \\
\hline Crystal size $\left(\mathrm{mm}^{3}\right)$ & $0.28 \times 0.24 \times 0.21$ \\
\hline$\theta$ range for data collection $\left({ }^{\circ}\right)$ & $1.52-25.01$ \\
\hline Limiting indices & $\begin{array}{l}-18<=\mathrm{h}<=18,-9<=\mathrm{k}<=9 \\
-19<=1<=18\end{array}$ \\
\hline Reflection collected & 9234 \\
\hline Independent reflection & $3452\left(\mathrm{R}_{\mathrm{int}}=0.0545\right)$ \\
\hline Completeness to $\theta_{\max }(\%)$ & 97.0 \\
\hline Data/restraints/parameters & $3452 / 348 / 236$ \\
\hline Goodness-of-fit on $\mathrm{F}^{2}$ & 1.102 \\
\hline Final $R$ indices $[I>2 \sigma(I)]$ & $\mathrm{R}_{1}=0.0920, \mathrm{wR}_{2}=0.2220$ \\
\hline $\mathrm{R}$ indices (all data) & $\mathrm{R}_{1}=0.1171, \mathrm{wR}_{2}=0.2434$ \\
\hline Largest diff.e peak and hole $\left(\mathrm{e} \mathrm{A}^{-3}\right)$ & 1.120 and -1.380 \\
\hline
\end{tabular}

TABLE-2

\begin{tabular}{cc}
\hline Bond lengths & X-ray crystal \\
\hline $\mathrm{Ni}(1)-\mathrm{P}(1)$ & $2.1437(19)$ \\
$\mathrm{Ni}(1)-\mathrm{S}(1)$ & $2.267(2)$ \\
$\mathrm{N}(1)-\mathrm{C}(14)$ & $1.291(10)$ \\
$\mathrm{P}(1)-\mathrm{C}(2)$ & $1.815(8)$ \\
$\mathrm{P}(1)-\mathrm{C}(1)$ & $1.820(7)$ \\
$\mathrm{P}(1)-\mathrm{C}(8)$ & $1.807(7)$ \\
$\mathrm{S}(1)-\mathrm{C}(14)$ & $1.714(8)$ \\
$\mathrm{S}(2)-\mathrm{C}(14)$ & $1.762(8)$ \\
\hline
\end{tabular}

\begin{tabular}{|cc}
\multicolumn{2}{c}{ TABLE-3 } \\
\hline Bond angles & X-ray crystal \\
\hline $\mathrm{P}(1)-\mathrm{Ni}(1)-\mathrm{P}(1 \mathrm{~A})$ & $87.92(10)$ \\
$\mathrm{P}(1)-\mathrm{Ni}(1)-\mathrm{S}(1)$ & $176.19(8)$ \\
$\mathrm{P}(1)-\mathrm{Ni}(1)-\mathrm{S}(1 \mathrm{~A})$ & $88.41(7)$ \\
$\mathrm{S}(1)-\mathrm{Ni}(1)-\mathrm{S}(1 \mathrm{~A})$ & $95.28(11)$ \\
$\mathrm{C}(14)-\mathrm{S}(1)-\mathrm{Ni}(1)$ & $91.8(3)$ \\
$\mathrm{C}(15)-\mathrm{S}(2)-\mathrm{C}(14)$ & $88.8(5)$ \\
$\mathrm{C}(14)-\mathrm{N}(1)-\mathrm{C}(16)$ & $112.2(8)$ \\
$\mathrm{C}(1)-\mathrm{P}(1)-\mathrm{Ni}(1)$ & $109.0(2)$ \\
\hline
\end{tabular}

complex (dppe)Ni(pdt) (Ni(1)-P(1)= 2.1637(7) $\AA$; Ni(1)-P(2) $=2.1554(7) \AA$ ), while the $\mathrm{Ni}(1)-\mathrm{S}(1)$ bond length (2.267(2) $\AA$ ) is slightly longer than the corresponding bond of complex $($ dppe $) \mathrm{Ni}(\mathrm{pdt})(\mathrm{Ni}(1)-\mathrm{S}(1)=2.1966(7) \AA ; \mathrm{Ni}(1)-\mathrm{S}(2)=$ 2.2077(7) $\AA)^{14}$. The selected bond angels $\mathrm{P}(1)-\mathrm{Ni}(1)-\mathrm{P}(1 \mathrm{~A})$ 87.92(10) ${ }^{\circ}, \mathrm{P}(1)-\mathrm{Ni}(1)-\mathrm{S}(1 \mathrm{~A}) 88.41(7)^{\circ}, \mathrm{S}(1)-\mathrm{Ni}(1)-\mathrm{S}(1 \mathrm{~A})$ 95.28(11) ${ }^{\circ}, \mathrm{P}(1 \mathrm{~A})-\mathrm{Ni}(1)-\mathrm{S}(1) 88.41(7)^{\circ}$ for the title complex (I) indicated that the coordination geometry around nickel is distorted from an ideal arrangement (sum of the angles is 


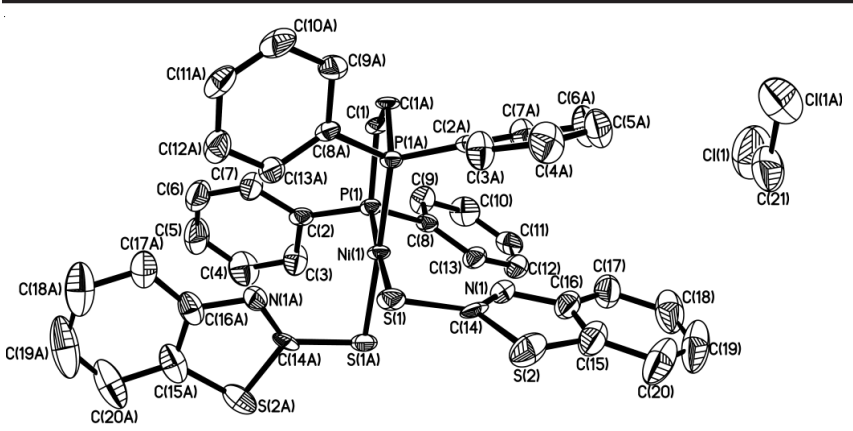

Fig. 1. Molecular structure of (I) with $30 \%$ probability thermal ellipsoids

$\left.360.02^{\circ}\right)$. The bond angels $\mathrm{C}(14)-\mathrm{S}(1)-\mathrm{Ni}(1)$ and $\mathrm{C}(14 \mathrm{~A})-$ $\mathrm{S}(1 \mathrm{~A})-\mathrm{Ni}(1)$ are both $91.8(3)^{\circ}$, the bond angel $\mathrm{P}(1)-\mathrm{Ni}(1)-\mathrm{S}(1)$ is $176.19(8)^{\circ}$. In addition, as shown in Fig. 2, a lD linear chain is formed via $\mathrm{S} \cdots \mathrm{H}$ intramolecular interactions. The distances of S1B and H1, S1AA and H1A are both $2.919 \AA$.

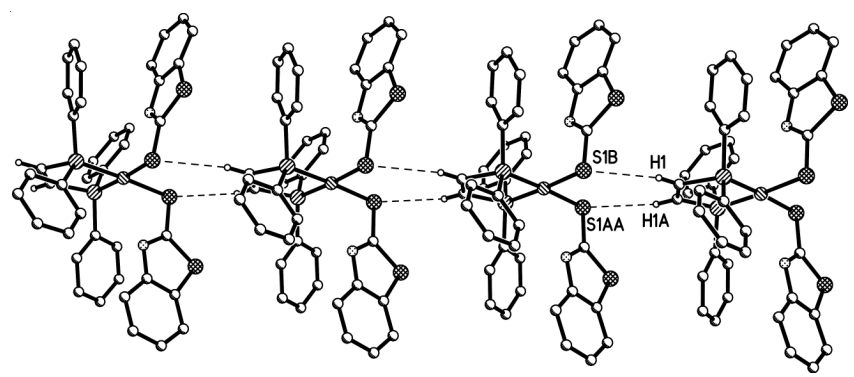

Fig. 2. Crystal packing diagram of (I)

TGA analysis: To reveal the thermal stabilities of the title complex, TGA measurement has been carried out on a NETZSCH STA 409 PC/PG instrument with a flow of dry air at a heating rate of $5{ }^{\circ} \mathrm{C} / \mathrm{min}$ from room temperature to $1000{ }^{\circ} \mathrm{C}$, shown in Fig. 3. The TGA curve indicates that the weight loss below $240{ }^{\circ} \mathrm{C}$ is $20.22 \%$, which is attributed to 2-mercaptobenzothiazole molecule (Cacld. $21.1 \%$ ). With the temperature increasing to $400{ }^{\circ} \mathrm{C}$, the ligand $\mathrm{dppv}$ and 2-mercaptobenzothiazole are completely decomposed.

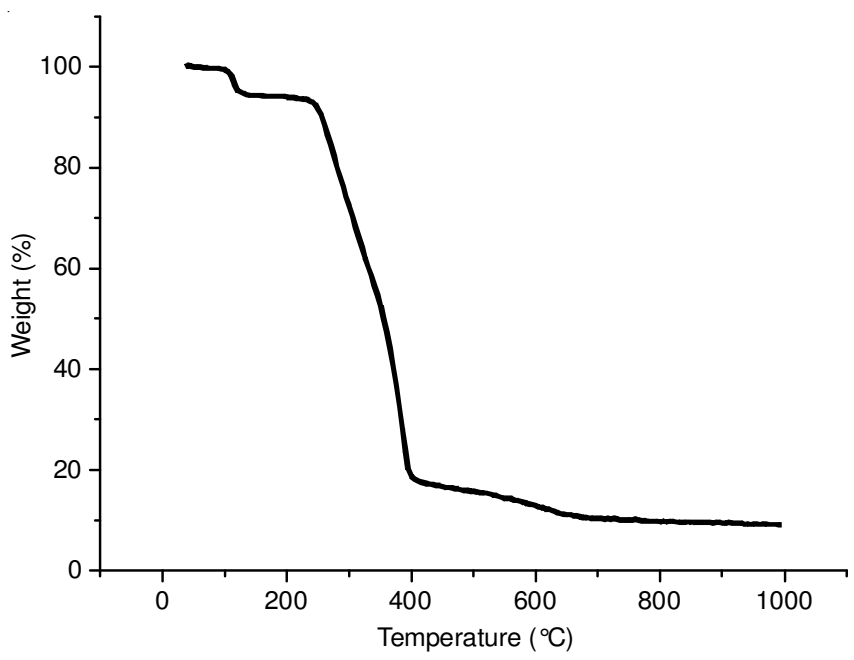

Fig. 3. TG curve for (I)

\section{Conclusion}

In summary, the nickel complex (dppv) $\mathrm{Ni}\left(\mathrm{C}_{7} \mathrm{H}_{4} \mathrm{NS}_{2}\right)_{2}$ (I) has been synthesized and structurally characterized by elemental analysis, TGA, IR and ${ }^{1} \mathrm{H}\left({ }^{13} \mathrm{C},{ }^{31} \mathrm{P}\right) \mathrm{NMR}$ spectra. Particularly, the molecular structure of the complex (I) was determined by single-crystal X-ray diffraction analysis.

\section{Supplementary data}

CCDC-914957 contains the supplementary crystallographic data for this paper. These data can be obtained free of charge via http://www.ccdc.cam.ac.uk/conts/retrieving.html, or from the Cambridge Crystallographic Data Centre, 12 Union Road Cambridge CB2 1EZ, UK (Fax: +44-1223-336033; or E-mail: deposit@ccdc.cam.ac.uk).

\section{ACKNOWLEDGEMENTS}

The authors are grateful to Science \& Technology Department of Sichuan Province (2012JY0115, 2011JY0052, 2010GZ0130), Sichuan University of Science \& Engineering (2011RC06, 2012PY04, 2012PY14) for financial support.

\section{REFERENCES}

1. S. Saito, M. Sakai and N. Miyaura, Tetrahedron Lett., 37, 2993 (1996).

2. S. Saito, S. Oh-tani and N. Miyaura, J. Org. Chem., 62, 8024 (1997).

3. V. Percec, J.Y. Bae and D.H. Hill, J. Org. Chem., 60, 1060 (1995).

4. M. Ueda, S. Saito, S. Oh-tani and N. Miyaura, Tetrahedron., 54, 13079 (1998).

5. A.S.E. Karlström, K. Itami and J.-E. Bäckvall, J. Org. Chem., 64, 1745 (1999).

6. A. Volbeda, M.H. Charon, C. Piras, E.C. Hatchikian, M. Frey and J.C. Fontecilla-Camps, Nature, 373, 580 (1995).

7. M. Cowie, R.L. DeKock, T.R. Wagenmaker, D. Seyferth, R.A. Henderson and M.K. Gallagher, Organometallics., 8, 119 (1989).

8. A.A. Lozano, M.D. Santana, G. Garcia, J.E. Barclay, S.C. Davies and D.J. Evans, Z. Anorg. Allg. Chem., 631, 2062 (2005).

9. W.H. Watson, A. Nagl, M.J. Don and M.J. Richmond, J. Chem. Crystallogr., 29, 871 (1999).

10. L.-L. Duan, M. Wang, P. Li, N. Wang, F.-J. Wang and L.-C. Sun, Inrog. Chim. Acta, 362, 372 (2009).

11. J.-F. Jiang, M. Maruani, J. Solaimanzadeh, W.-F. Lo, S.A. Koch and M. Millar, Inorg. Chem., 48, 6359 (2009).

12. M. Schmidt and G.G. Hoffmann, Chem. Ber., 112, 2190 (1979).

13. M. Schmidt and G.G. Hoffmann, J. Organomet. Chem., 124, C5 (1977).

14. W.-F. Zhu, A.C. Marr, Q. Wang, F. Neese, D.J.E. Spencer, A.J. Blake, P.A. Cooke, C. Wilson and M. Schröder, Proc. Natl. Acad. Sci. USA, 102, 102 (2005).

15. J.A.S. Bomfim, F.P. de Souza, C.A.L. Filgueiras, A.G. de Sousa and M.T.P. Gambardella. Polyhedron, 22, 1567 (2003).

16. Crystalclear and Crystalstructure, Rigaku and Rigaku Americas. 9009 New Trails Dr. The Woodlands TX 77381 USA.

17. G.M. Sheldrick, SHELXS97, A Program for Crystal Structure Solution, University of Göttingen: Germany (1997).

18. G.M. Sheldrick, SHELXS97, A Program for Crystal Structure Refinement, University of Göttingen: Germany (1997). 